\title{
İsmet Özel'in Şiirlerinde 1965-1975 Dönemi Siyasî Olayları ve Halka Bakış
}

\section{İsmet Özel's Perspective on Turkish Society and Political Events in his Poetry during 1965-1975 Period}

\author{
Celal Fedai ${ }^{1 \oplus}$
}

'Dr., Milli Eğitim Bakanlığı, İstanbul, Türkive

Sorumlu yazar/Corresponding author: Celal Fedai,

Milli Eğitim Bakanlığı, Yenişehir Mah., Millet Caddesi, Gökçeren Sitesi, B Blok No: 23 Kurtköy, Pendik, İstanbul, Türkiye

E-mail: fedai.celal@gmail.com

Geliş tarihi/Date of receipt: 25.09.2018 Kabul tarihi/Date of acceptance: 29.10.2018

\section{Atıf/Citation:}

Fedai, C. (2018). İsmet Özel'in şiirlerinde 19651975 dönemi siyasî olayları ve halka bakış. TUDED 58(2), 375-397.

https://doi.org/10.26650/TUDED478092

\begin{abstract}
ÖZET
1960 sonrası Türk şiirinin önemli simalarından biri olan İsmet Özel (d.1944), yalnız Türk şiirini değil düşünce dünyasını da etkileyen bir isim olmuştur. Özel'in ilk şiirlerinde İkinci Yeni şiirinin izleri görülür. Bu şiirlerinde, varoluşunu iç dünyasında sürdürür. 1960'ı yılların ortalarında, sosyalist dünya görüşünün etkisiyle şiirler yazmaya başlayan şair, Evet, İsyan (1969) ve Cinayetler Kitabı (1975) adlı eserlerindeki şiirlerinde, 1965-1975 dönemi Türk toplumundaki siyasî mücadelelerin, çatışmaların etkilerini, görünümlerini yansıtmıştır. Toplumsal, siyasî olaylara sosyalist bir gözle yaklaşır. İşçi, öğrenci olaylarını şiirlerine taşır. Türkiye ve dünyada yaşanan aktüel meseleleri şiirleri aracılığıyla yorumlar. Sorumluluk duygusuyla hareket ettiğini düşünür. Şair bu döneminde "sosyalist gerçekçi" bir sanat anlayışına yakındır. Ancak bireysel dünyasını da ortaya koymak ister. Böylelikle sosyalist gerçekçi diğer şairlerin düştüğü kimi hataları tekrarlamak istemez. 1974'ten sonra siyasî görüşlerinde köklü bir değişim yaşayan şair, İslamî bir dünya görüşüyle yazdığı eserlerle karşımıza çıkar. Bu çalışmada İsmet Özel'in 1965-1975 döneminde yayımladığı şiirlerinde dönemin siyasî hadiselerinin izleri ve şairin bu hadiselere yaklaşımında önemli bir etken olan halka bakışı tespit edilmeye çalışılacaktır.
\end{abstract}

Anahtar Kelimeler: İsmet Özel, sosyalist gerçekçilik, siyasî çatışma, işçi olayları, halk

\section{ABSTRACT}

İsmet Özel (b.1944) is one of the most important figures of Turkish poetry after 1960, and his name is important in Turkish literature. His writing influenced Turkish poetry and the Turkish world of thought. In Özel's first poems, there are traces of the İkinci Yeni Movement. In these poems, he continues the raisond'être of his inner world. In the mid-1960s, his writing began to show the influence of a socialist world view. Özel reflects these effects and the appearances of the current political struggles and conflicts in Turkish society during the period from 1965-1975. These poems are found in his books Evet, isyan (1969) and Cinayetler Kitabı (1975). He approaches social and political events with a socialist eye. He makes room in his poems to think about worker and student revolts during this period. Özel interprets Turkey's and the world's current issues through his poems. He believes he is acting with a sense of responsibility. During this period, his writing takes a closer stance toward the "socialist realist" understanding of art. On the other hand, he also wants to represent his individual world. Thus, he does not want to repeat some of the mistakes other socialist realist poets made. After 1975, he made radical changes in his political views and came up with his works, which were written from an Islamic world view. This study examines and traces the political events of the 1965-1975 period in İsmet Özel's poetry and his perspective on society as an important element of his approach toward these political events.

Keywords: İsmet Özel, socialist realism, political conflict, labor revolts, society 


\section{EXTENDED ABSTRACT}

Ismet Özel (b.1944) is one of the most important figures of Turkish poetry after 1960, and his name is important in Turkish literature. His writing influenced Turkish poetry and the Turkish world of thought. In Özel's first poems, there are traces of the Ikinci Yeni Movement. In these poems, he continues the raisond'être of his inner world. We see his specific imagination. The musical aesthetics which were disregarded by Ikinci Yeni Movement poems are also an important element of his poems. His first book of poetry Geceleyin Bir Koşu (1966) draws attention to these characteristics.

During the mid-1960s, his writing began to show the influence of a socialist world view. Özel reflects these effects and the appearances of the current political struggles and conflicts in Turkish society during the period from 1965-1975. These poems are found in his books Evet, Isyan (1969) and Cinayetler Kitabı (1975). He approaches social and political events from a socialist perspective. He interprets current issues in both Turkey and the world through his poetry. He also thinks he is acting with a sense of responsibility. For instance, his poems reference the strikes by the mine workers in Zonguldak, and he wants to support them through his poems. His poems "Partizan", "Propaganda", and "Yıkılma Sakın" express his revolutionary lyricism. However, these attempts face poetic complications which may lead to the loss of the characteristics that makes his poems "poems".

The poet aligns himself more closely with a socialist realist understanding of art during this period. Hence, İsmet Özel tends to use poetry as a part of his political actions, and he also tends to reveal his individual world. Thus, he does not want to repeat the mistakes other socialist realist poets have made. His perception of the public during these years is mostly romantic. However, it is worth emphasizing his strong sense of self. Özel shows special interest in the political events of his period. Socialist realism, which evolved into literary expression along with the decisions made by the Soviet Writers Union Congress under the chairmanship of Maksim Gorki, begins to affect the writers of this period. Socialist realism, which gained the status of an original theory of literature in the 1940s through the writings of Georg Lukacs, imposes a political responsibility on writers. This tendency, which started in Turkey with the poet Nazım Hikmet, represents the efforts in the field of literature to create a socialist revolution in Turkey together with his friends Ataol Behramoğlu, Süreyya Berfe and Özkan Mert. Together, they manifested a poetic and political attitude against the İkinci Yeni Movement poets, whom they perceived as unsuccessful in terms of combining poetry with political action, in Ant magazine in the year 1969. The journal Halkın Dostları, which was published by the poet, represents the continuation of this attitude. Halkın Dostları also perceives his poetry as a catalyst for a possible socialist revolution in Turkey. Hence, he shows a firm position toward the other poetry movements. 
After 1974, İsmet Özel underwent radical changes in his political views and came up with his works, which were written mostly from an Islamic world view. After March 12, 1970, the political atmosphere coup paved the way for the poet's self-questioning. This process, which went on for about four years, is also echoed in Özel's poems. Published in the Diriliş journal, the poem "Amentü", actually reveals the change in his inner world as well as in his perception of society. Similarly, his disposition toward the political events of the time period also decreased, and a broader outlook emerged. This study examines the traces of the political events from the 1965-1975 period in İsmet Özel's poetry and his perspective on society as an important element of his approach toward these political events. 


\section{Giriş: Sosyalist Gerçekçilikle Birlikte Değişen Şiir - Siyaset İlişkisi}

Edebî eser, sanatçının iç dünyasından kaynaklanabileceği gibi toplumun sanatçı kişilik üzerindeki türlü etkilerinden de oluşabilir. Bu bakımdan edebî eseri tek boyutlu bir yapı olarak düşünmek doğru olmayacaktır. Bilhassa toplumsal değişimlerin, çatışmaların arttığı dönemlerde sanatçıların farklı tepkiler verdikleri görülür. Bazı sanatçılar böyle dönemlerde içe kapanık bir dünyanın imgelerle örülü, soyut bir eserini önümüze koyarken bazıları siyasî, sosyal bir sorumluluğu üstlenmeyi tercih eder. Sanatçı kişilik farklı dönemlerinde farklı sanat eğilimleri içinde yer alabilir. Hatta böyle olmayı bir gelişme olarak da görebilir. Ancak her durumda toplumu etkileyen siyasî hadiselerden en çok etkilenenlerin başında şairler, yazarlar gelir.

Edebiyatımızın kimi dönemleri, siyasîhareketliliğin etkisinde kalmak bakımından özellikle dikkat çeker. 1960-1980 dönemi de böyle bir dönemdir. 27 Mayıs 1960'da gerçekleştirilen askerî darbeden sonra Türkiye'de siyasî ve sosyal olaylar evvelce görülmedik bir hüviyet kazanır. Bunda Türkiye'nin darbe sonrasında oluşan iç dinamikleri kadar başta Avrupa olmak üzere tüm dünyada yükselen sol düşüncenin de etkisi söz konusudur. "Ekim Devrimi" sonrası Rusya'da oluşan sosyalist devlet modeli, başka ülkelerdeki sosyalistler için de devrim projelerini daha çok beslemeye başlar. Devrimin öncülerinden Lenin'in 1926'da ölümü sonrası Rusya'da iktidarı ele geçiren Stalin, muhalifi Troçki'nin aksine, tüm dünyadaki sosyalist hareketleri Rusya'ya bağlamak düşüncesindedir (Oktay, 1984, s.105-136). Sanatçıları "insan ruhunun mühendisleri" olarak gören Stalin, 17 Ağustos 1934'te Moskova'da düzenlenen Sovyet Yazarlar Birliği Kongresi'nde, sonradan Georg Lukacs tarafından bir edebiyat, sanat kuramına dönüştürülecek olan "sosyalist gerçekçilik"i, siyasî projelerinde etkili bir şekilde kullanır. Bilhassa Jdanov, Lunaçarski gibi isimler, sosyalist gerçekçiliği Rusya'da sosyalizmin resmî kuramı olarak yerleştirir (Artun, 2016, s. 158-159). Avrupa başta olmak üzere neredeyse tüm dünyada sanatçıların bir ideolojiye "bağlanma"ları hususu tartışılır hale gelir. Sanatçı böylelikle toplumu tarih içinde bir yere oturtacak, içindeki çatışmaları, ilerici ve tutucu güçleri fark edecek ve "sosyalizme doğru diyalektik gelişimi" görebilecektir. Yazar ancak bu yolla "çağımızın sosyal gerçekliğine sızabilir" (Moran, 1991, s. 49).

Stalin'in öngördüğü sanat kuramının fikir babası ve uygulayıcısı Markim Gorki'dir. 1934'te Moskova'da Sovyet Yazarlar Birliği kongresindeki bildiriyi sunma görevini de üstlenen Gorki'nin sanatçı kişiliği, sosyalist gerçekçiliğin sanatçıya yüklediği misyonun ne olduğunun anlaşılabilmesi açısından ele alınabilir. Elliülkeden altı yüzden fazla delegenin oturum başkanı seçtiği Gorki, konuşmasında, Sovyetler Birliği'nde edebiyat ve bilimin bir kardeşlik içinde birbirinden yardım aldığını ve bunun dünyanın hiçbir ülkesinde olmadığını vurgular. Kongre boyunca tüm katılımcılarla ilgilenir, oturumları dinler. Misafirlerini evinde ağırlar. Gorki'nin şahsında sosyalist gerçekçi yazar tipinin sorumlulukları belirginleşmiştir. Henri Troyat bu değişimi şu sözlerle somutlaştııır: "Gorki'nin başını çektiği delegeler, 'devrimci romantizm' adına Joyce'un, Proust'un ve Pirandello'nun eserlerini mahkûm ettiler: 'Ayağını gerçekten çekmeden, insanı kendinden yukarılara yükselt,' sözünü şiar edinmişlerdi. Kongrede oy birliği ile belirlenen kesin kararda, 'büyük proleter yazar Maksim Gorki'nin' ulusunun edebi 
dehasının gelişmesinde 'oynadığı olağanüstü önemli rol' vurgulanıyordu." (Troyat, 1991, s. 248-249). Dünyanın her yanındaki sosyalist gerçekçi sanatçılardan beklenenler böylece netleşmiştir. Toplumu ilgilendiren her çeşit gerçek, sanatçılar tarafından irdelenecek ve sosyalist gerçekçi kuramın gerektirdiği gibi sanat eserlerine aktarılacaktır.

Kıta Avrupası'nda Bertolt Brecht, Theodor Adorno, Georg Lukacs arasında 1940'larda bu doğrultuda yürütülen "gerçekçilik tartışmaları", Türkiye'yi de etkiler. Sosyalist gerçekçiliği, Rus Komünist Partisi'nin bir kuramı olmaktan çıkarıp bir edebiyat kuramı haline getiren Lukacs'ın yorumları, Kıta Avrupası'nda Brecht ve Adorno gibi isimlerin karşısında fazla tutunamasa da Türkiye'de 1940'lı yılların toplumcu yazarları onun kuramına ilgi gösterirler (Oktay, 1984, s. 148-197). Daha 1920'lerde sosyalist fikirlerle şiirlerini yazan Nâzım Hikmet'in bu doğrultuda açtığı çığır, 1930'lu yıllarda birçok genç şâiri etkisine alır. Ama bu genç şâirler, toplumcu çizgide kendilerine özgü bir şiiri geliştiremezler. Asıl bağlantı 1940'larda kurulur. Kimilerince, '1940 kuşağı' adıyla anılan bu sosyalist şâirler (Rıfat Ilgaz, Cahit Irgat, A. Kadir, Enver Gökçe, Ömer Faruk Toprak, Arif Damar, Ahmed Arif, Attila İlhan, Şükran Kurdakul vs.) toplumcu şiiri devam ettirip geliştirmeye çalışırlar (Gülendam, 2010, s. 224). 1930'larda Sadri Ertem, Ercüment Behzat Lav gibi romancı ve şairler ile Kerim Sadi ve A. Cerrahoğlu gibi yazarların bu husustaki katkılarını da anmak gerekir. 1940'da edebiyatımızda ilk sosyalist gerçekçi dergi olarak nitelenen ve Türkiye Komünist Partisi'nin "legal yayın organı" olarak işlev gören Yeni Edebiyat dergisi, yayın hayatına başlar (Ileri, 1998, s. 9). Suat Derviş üzerine yaptığı çalışma sırasında Yeni Edebiyat'la karşılaşan Wolfgang Riemann, Yeni Insanlık, Küllük ve Yeni Edebiyat dergileri arasında, "haleflik, seleflik" ilişkisi kurar. Ona göre, derginin adı değişmiş; yazar kadrosu, yazarları, yazarların siyasi eğilimleri ve işlenen temalar hemen hemen aynı kalmıştır (Riemann, 1998, s.149). Dergiyi çıkaran isimlerden Reşat Fuat Baraner, Türkiye Komünist Partisi'nin genel sekreteridir. Suat Derviş, Zeki Baştımar, Abidin Dino, Sabiha Sertel, Zekeriya Sertel gibi dönemin önde gelen isimlerinin eser verdiği dergi, sosyalist gerçekçi düşüncenin Türkiye'de bir temsilcisidir. Edebiyat, sanat, hayat üzerine dile gelen görüşlerin ilhamını Rusya'dan aldığı açıktır. Rusya, Avrupa'daki sosyalist hareketleri desteklediği gibi Türkiye'deki sosyalist hareketleri de yönlendirmektedir (Oktay 1984, s.169-515).

1960'lı yılların fikir hayatına yön veren eğilimlerin hâkim unsurunu, sosyalist görüşlerin farklı alanlardaki tezahürlerinin oluşturduğunu söylemek yanlış olmaz. Amerika Birleşik Devletleri ve Sovyetler Birliği arasında, İkinci Dünya Savaşı sonrası başlayan soğuk savaş ortamı, askerî alanlarda olduğu kadar sanat, edebiyat ve düşünce alanında da kendini gösterir (Saunders, 2016, s. 21-99). 1960'lı yıllara egemen olan atmosfer, Sovyetler Birliği'nden yayılan sosyalizm dalgasıdır. Bu dalga, dönemin aktüel siyasî olayları arasında en çok dikkat çekenlerden olan işçi ve öğrenci olaylarının arkasındaki ideolojik geri planı görmemiz açısından önem arz eder.

6 Ocak 1968'de, "Vietnam kasabı" olarak adlandırılan ABD büyükelçisi Robert W. Komer'in makam arabasının ODTÜ'nün bahçesinde üç üniversite öğrencisi tarafından 
yakılmasıyla başladığı için "68 Kuşağı" olarak anılacak olan bu döneme adını veren şeyin arkasında sosyalist devrim düşüncesi yatmaktadır (Sezer, 2008, s. 11). Dönemin sol tandanslı şairleri, yazarları, toplumda sosyalist bir devrimin hazırlayıcısı olmak adına türlü roller üstlenmişlerdir. Kimi toplumdaki çatışma alanlarını öykülerinde, tiyatrolarında konu edinir, kimi toplumda geriliğin kaynağı olarak gördüğü dinî inanışları romanlarında ele alır, kimi de aktüel siyasî olayları şiirlerinin siyasî mesajını ileten bir fon olarak kullanır. Söz gelimi, bu eğilimin ilk olduğu kadar en çarpıcı örneklerini de veren Nâzım Hikmet, Marshall yardımı ile halka dağıtılan ilaçlı buğdayların yenmesi sonucu oluşan "kara yara" hastalığını aynı adı taşıyan şiirinde söyle anlatır:

\author{
Birinci sayfada yatıyor iki sütun üstüne \\ iki çıplak yavrucuk, \\ birinci sayfada iki sütun üstüne \\ bir avuç kemik deri. \\ Delinmiş patlamış etleri. \\ Biri Diyarbakırlı, Erganili biri. \\ Kolları bacakları kargacık burgacık, \\ kafaları kocaman, \\ ağızları korkunç bir haykırışla açık, \\ birinci sayfada taşla ezilmiş iki kurbağacık. \\ iki kurbağacık \\ kara yaralı iki yavrum benim. \\ Yılda kim bilir kaç bininiz \\ acı suya bile doymadan gelip gidiyor... \\ Ve müsteşar bey: \\ (Kara Yaraya tutulası) \\ "Endişeye mahal yok," diyor (Hikmet, 2012, s. 26).
}

1950'de iktidara gelen Demokrat Parti yönetimini Amerikan yanlısı olarak gören sosyalist yazar, şair ve akademisyenlerin yönlendirmesiyle pek çok işçi ve öğrenci olayları gerçekleşir. Bu olaylar, 1959 yılında toplumsal hayatı derinden etkileyecek noktaya ulaşır. 28 Nisan 1959'da İstanbul'da üniversite öğrencisi Turan Emeksiz'in öldürülmesiyle başlayan olaylar bir gün sonra Ankara'ya da sıçrar (Sezer, 2008, s. 24-29). Cemal Süreya'nın “beşinci ayın beşinci günü Kızılay'da buluşalım" parolasını ifade eden $555 \mathrm{~K}$ şiiri, o günlerin havasını vermesi açısından dikkate değerdir:

Biz şimdi alçak sesle konuşuyoruz ya

Sessizce birleşip sessizce ayrılıyoruz ya

Anamı çay demliyor ya güzel günlere

Sevgilimizse çiçekler koyuyor ya bardağa

Sabahları işimize gidiyoruz ya sessiz sedasız 
Bu, böyle gidecek demek değil bu işler

Biz şimdi yan yana geliyoruz ve çoğalıyoruz

Ama bir ağızdan tutturduğumuz gün hürlüğün havasını

Işste o gün sizi tanrılar bile kurtaramaz (Süreya, 1995, s. 184).

27 Mayıs 1960 askerî darbesini oluşturan siyasî atmosferin dönemin şairlerinin şiirlerine yansımasından da görülebileceği gibi 1960'lı yılların edebiyat eğilimlerinden olan sosyalist gerçekçilik, bu düşünceye sahip sanatçıdan mutlak bir siyasî bağlanmayı talep etmektedir. 1950'li yılların ortasında Türk şiirinde modern Batı şiirinin imkânlarını kullanarak oluşan İkinci Yeni şairleri, sosyalist görüşlere eğilimli olsalar da böylesi bir bağlanmayı sanatçının bağımsızlığı açısından sorunlu bulurlar. Yukarıda 555K şiiriyle andığımız, ironik bir bakışla sosyal olayları yorumlayan Cemal Süreya; 1970'de yayımlanan Divan adlı kitabında siyasî, sosyal meselelere, tarihî arka planlarıyla birlikte göndermeler yapan Turgut Uyar; 1973'de yayımlanan Devlet ve Tabiat kitabında tarih boyunca iktidar karşısında ayrıksı bireyin serüvenini arayan Ece Ayhan başta olmak üzere, diğer İkinci Yeni şairleri de esasen siyasî, sosyal olaylara şiirlerinde yer verirler. Ancak onlar şiirin estetik niteliklerini koruma konusunda da hassasiyet gösterirler. Bu noktada, II. Yeni şairleri ile sosyalist gerçekçiler arasında, İsmet Özel'in "Partizan" şiiriyle ilgili Edip Cansever'in eleştirilerini söz konusu ederken izah etmeye çalışacağımız türden bir poetik tercih farklılığı söz konusudur.

1950'lerin sonlarında adı İkinci Yeni şiiri içinde anılan Kemal Özer'in bu noktadaki durumu dikkat çekicidir. Özer, ilk şiir kitabı Gül Yordamı (1959) ile İkinci Yeni şiirinin imkânlarından oldukça başarılı bir şekilde faydalanarak bir şiir dili geliştirir. Lakin Özer'in siyasî düşünceleri onu sosyalist gerçekçi olmaya doğru yönlendirmektedir. Neticede şair, ikinci kitabından itibaren sosyalist gerçekçi söylemi tercih eder. Tutsak Kan (1963), Kavganın Yüreği (1973), Sen De Katılmalısın Yaşamı Savunmaya (1975) kitapları onun bu yöneliminin en belirgin örnekleridir.

Kemal Özer'in geçirdiği değişimin, hem İsmet Özel'in değişimini hem de dönemin şairlerinin genel durumunu ortaya koyabilmek açısından örnek teşkil ettiği için üzerinde durulmasında fayda görüyoruz. Şairin Gül Yordamı kitabında bulunan "Halklı" şiiri, bu bakımdan mühimdir:

çizdim yalnızlığıma bir koyu halk getiren

en acı gözleriyle duvara o aslanı

her bakışta bir onulmaz çılgınlığı sürdüren

aslanların bu en fazla kalabalık olanı

üstüne aşk vuranı gördüğü her dişiden

kurtarsın diye çizdim tutsak çadırlarından

tüylerinde o uzun o kara afrika'yı 
her biri bir ölüm gözleriyle hatırlanan
güneşte bırakılmıs dövülmüş omuzları
kurtarsın diye çizdim soylu acılarından
soylu bir bakıştır o damları arkasında
ay gibi sızlanan o tertemiz bir akşamın
düşer en beyaz gergefe kızlar ağladığında
toprağa düşer gibi en güzel gülü kanın
bir tükenmez bıçaktır sırtımın ortasında (Özer, 1959, s. 18-19)

Özer'in“Halkı” şiiri, 1960'lı yılların sosyalist gerçekçi şairlerinin halka bakışını göstermesi bakımından dikkat çekicidir. Şiirde açıkça görülebileceği gibi şair, halkı bir aslan olarak niteler. $\mathrm{O}$, kalabalık bir grupla gezen aslan ailesi içinde "en kalabalık" olandır. Şiirin öznesi olan halk, henüz bir tasarımdır. Bu düşsel tasarım, bir başka halkın, Afrika halkının kurtarıcısı olacaktır. Şair, onun bu uğurda toprağa düşen kanı ile beyaz gergefe eğilen kızlar arasında bir bağ kurar. Kendi ile arasında kurduğu bağ ise "bir tükenmez bıçaktır sırtımın ortasında" dizesinde belirginlik kazanır.

Kemal Özer, "halk"ı, "sırtının ortasında bir bıçak" gibi görmez. Şair bu şekilde uğradığı ihanetleri sembolize eder gibidir. Ancak, 1960'lı yıllardan 1980'li yıllara kadar Türk şairleri için "halk" ve "siyaset", birbirinden ayrılmaz iki kavramdır. Sosyalist gerçekçi şairler, halka dair her hususu şiirlerinde işlemek zorunluluğu duyarlar. Halkın giyim kuşamından yoksulluğuna, işçi grevlerinden öğrenci olaylarına kadar onu ilgilendiren her husus, onlar için şiirin gerçek konusu haline gelmiştir.

\section{2. İsmet Özel'in Halka Bakışının Şiirlerine Yansıması}

Kemal Özer gibi ilk şiir kitabında İkinci Yeni şiirinin etkisi altında kalan İsmet Özel de 1960'lı yılların ortalarından itibaren benzer bir süreç geçirerek sosyalist gerçekçi bir şiire meyleder. Özel, Halkın Dostları dergisini birlikte çıkardığı Ataol Behramoğlu'na yazdığı bir mektubunda "beynim hep yaratılacak Büyük Türk Halkı ile meşgul" diye yazacaktır. Ona göre de sosyalist devrim için halkın siyasî, sosyal bir hazırlığa ihtiyacı vardır (Özel, 1995, s. 76).

İsmet Özel'in ilk şiir kitabı Geceleyin Bir Koşu, dünyadaki duruşunu, iç dünyasının karmaşası içinde arayıp çözmeye çalışan bir bireyin imgelemini sunar. Şair, 1962-1966 yıllarını kapsayan bu şiirleri henüz kitaplaşmadan siyasî yönelimleriyle belirginleşen bir şiir yazmaya başladığının farkında olduğu için kitabının bir an önce yayımlanmasını ister. Gerçekten de kitap yayımlandığı yıl İsmet Özel, 1960'lı yılların siyasî atmosferinin etkisiyle siyasî bir söyleme yaslanan şiirler yazmaya başlar. Tabir caizse şiiri, bıçak gibi ikiye bölünür bir görünüm kazanır. Ancak hemen söylemek gerekir ki bu şiirler, iç dünyalarını değersizleştirme pahasına sosyalist gerçekçi kurama bağlanan dönemin pek çok şairinin şiirlerinden farklıdır. Özel'in derin ve zengin bireysel dünyasını yansıtır. 
İsmet Özel, toplumsal olaylara bir sosyalist olarak eğildiğinde şiirsel yeteneklerinin ona verdiği imkânlardan vazgeçmemeyi başarabilme gayreti içindedir. Dönemin pek çok şairi, 1930'lardan beri, benzer sorunlar yaşayan sosyalist gerçekçi eski kuşak şairler gibi yapmakta ve klişe üreten bir şiir yazmaktadır. İsmet Özel ise, 1969'da yayımlanan Evet, İsyan ve 1975 tarihli Cinayetler Kitabı'nda görülebileceği gibi siyasî söyleme yaslandığında şiir estetiğinden taviz vermeyen bir tutumu benimsemenin imkânlarını araştırmaktadır. Bu durumu somutlaştırmak açısından Özel'in halka bakışını yansıtmak yerinde olacaktır.

İsmet Özel'in "halk" temasının ağırlıklı olarak yer aldığı ilk şiiri 1966 yılında yayımlanan "Evet, İsyan" şiiridir. 1969 yılında şairin ikinci şiir kitabına da ad olacak bu şiir, Carl Sandburg'un "Evet, İnsan" şiirine karşı, devrimci bir şairin manifestosu niteliği taşır (Özel, 1991, s. 55). Devrimci mücadelesinin coşkusuyla dolan şair, bir yandan bu coşkuyu aşk ile bütünleştirirken diğer yandan da halka olan bakışını gösterir:

\author{
ben karakavruk yüzümün arkasında \\ kırbaçlayarak büyüttüğüm ağrıyı bırakıyorum \\ bana ne çerçilerden, çerilerden, kullardan \\ halksa kal'am onu kal'a kılan benim \\ boşanır damarlarıma yılların kahraman gürültüsü \\ çünkü kavganın göbeğidir benim yerim. \\ Ay vurunca çatlatır göğsümdeki mahşeri \\ çünkü kavganın göbeğidir benim yerim (Özel, 1967, s. 28-29)
}

Şiirde Özel'in "halk"ın bir "kal'a" olmasını sağlayan şeyin bizzat kendisi olduğuna dair vurgusu gözlerden kaçmamaktadır. Onu, Kemal Özer'den ve dönemin öteki şairlerinden ayıran husus, kanaatimizce burada yatmaktadır. Bir devrimci olarak şairin halkına yönelik sevgisi açıktır ama bu sevginin kaynağı ve gücü şairin kendisindedir. Bu nedenle de sevgide belirleyici olan şairdir. Devrimci mücadelenin her alanı için de aynı durum söz konusudur. Hatta şairi coşturan aşk için bile:

\author{
Ben merd-i meydan \\ yani toprağın ve kanın gürzü \\ güllerin bin yıllık mezarı bendedir \\ yukardan bakarım efendilerin pusatlarına \\ insanların bütün sabahlarını merak ederim \\ gök hırpalanmaktadır merakımdan \\ ıtır kokan benim yumruklarımdır \\ benim kavgamdır o, aşk diye tanınan (Özel, 1967, s. 28-29)
}

"Evet, İsyan" şiiri, İsmet Özel'in halka bakışında kurduğu "ben - halk" dengesinin ilk örneği olmasının yanında değişmeyen bir model olma özelliği de taşır. Zira şairin 1969'da 
yayımladığı "Yaşatan" şiiri, "Evet, İsyan”ın dengesini sürdürür. "Yaşatan”, baştan sona halk temasının hâkim olduğu bir şiirdir. Şiir, daha adından başlayarak şair için halkın anlamını verir. Halk, yaşatandır:

\author{
Ben halka bakınca gümüş tırnaklı kısraklar \\ sırça kirpikli gelinler huylanır. \\ Ben halka bakınca terlenirim \\ yaslanırım tarlaların gölgesine, tozuna \\ kirlenir gülkurusu mendilim. \\ Benim rengimle kim yarışabilir \\ sancımı kimler alt edebilir ben halka bakınca? \\ Ben ki kazdım, küredim, ellerimle boşalttım geceyi \\ yıldızları, hüznü oradan fırlatıp attım, \\ sonra ordan fırtınalı bir tüzeyle halka bakınca \\ yeniden yaralandım dünya ırmaklarından (Özel, 1969, s.22).
}

"Evet, İsyan" şiirinde olduğu gibi "Yaşatan"da da şair ile halk arasındaki sevgide belirleyici olan şairin benliğidir. Onun halka bakışıyla halk adeta başka bir güzelliğe erişir. Bu nedenle de üçüncü kişiler, nesneler, şair ile halk arasındaki sevgiyi kıskanır. Sevgiyi oluşturan eylemin tüm etken unsurları da yine şairden neşet etmektedir.

Bu noktada İsmet Özel'in şiirlerinde halka ilişkin meselelere niçin bu denli önem verdiği sorusunu da sormak yerinde olacaktır. Bu sorunun cevabını Özel'in 1966 yılında Ataol Behramoğlu'na yolladığı bir mektubunda bulmak mümkündür. Özel'e göre içinden çıktıkları toplum, devrimci şairler olarak onlara hem çok şey vermekte hem de onları sınırlamaktadır. Bu nedenle de devrimi düşüncede başlatmanın zorunluluğu vardır. Yazacakları şiir, sosyolojiye sıkı sıkıya bağlıdır: “(...) Neden toplumbilim? Psikoloji değil? Çünkü dünyayı, doğayı değiştirip yenmenin, böylece kendi kendini yenmenin tek yolu o da onun için. 'İş' toplumsal bir olgudur. Şiir de bir 'iş'dir" (Behramoğlu ve Özel, 1995, s. 43).

Özel'in "Evet, İsyan" şiirini sadece biçim yönünden eleştiren Ataol Behramoğlu'na yazdığı bu karşı eleştiriden de görülebileceği gibi o, içinden çıktığı toplumun onu sınırlayan yanlarını toplumbilimin düşünce imkânlarıyla aşmak istemektedir. Şiiri de bu nedenle bir "iş" olarak niteler. Bu yüzden bir devrimci şair olarak halka böyle bir duygu ve düşünce ile yönelmenin, "iş"ini eylemiş olmanın coşkusunu duyar. Özel'in halka bakışında benliğinin tuttuğu yeri ortaya koymak açısından 17 Aralık 1967 tarihli bir mektubunda Ataol Behramoğlu'na yazdığı şu sözler de mühimdir: "Halk sanıldığı kadar büyük bir zenginlik taşımıyor ülkemizde. Bunu şimdi âlem yapan çavuşlara bakarak yazıyorum. Duyguları, beğenileri, ahlak telakkileri yüzeyde. Nasıl sınıf ayrımları belirgin değilse aynı biçimde yaygın bir kasabalı psikolojisi. Her neyse daha iyi bakmak gerek" (Behramoğlu ve Özel, 1995, s. 52). 
İsmet Özel'in halka bakışı, poetik, politik boyutlarının yanında kendisi ile halk arasında süren bir arayışı ifade eder. Şair bu arayışta halkın ağzında yaşayan kelimeleri özenle seçip şiirlerine yerleştirir. Halk yaşantısının sıkıntılarına kadar pek çok unsuru şiirlerine mal eder. Dönemin öteki sosyalist gerçekçi şairleri için de benzer bir durumdan söz edilebilir. Sözgelimi Süreyya Berfe'nin ilk şiir kitabı Gün Ola'daki şiirlerin neredeyse tamamında, şiirlerin halk yaşantısı etrafında geliştiği görülür. Pek çok şiirin başlığında "türkü” ibaresi yer alır. Türkülerden alıntılara sıkça başvurulur. Köylülerin dünyası çeşitli yönleri ile yansıtılmaya çalışılır. Özel gibi Berfe de "halk" kavramına daha önceki sosyalist gerçekçi şairlerden farklı bir anlam yüklemeye çalışmaktadır. Fikir Kulüpleri Federasyonu'nun ilk yayını olarak basılan Gün Ola'nın sunuşunda, şu dikkat çekici görüşlerle şiir takdim edilir: "Yaptığımız eylemler sürüp gitmekte. Dün hakkında neler düşündüğümüz belli. (...) Genç ozan, arkadaşımız, Süreyya Berfe'nin şiirlerini sunuyoruz size. Bu dönemdeki sanat görüşümüzü, sanatımızla neyi yapmak istediğimizi ortaya koyuyor, tartışmaya sunuyoruz." (Berfe, 1969, s. 3) 1960 kuşağı sosyalist gerçekçi şairleri; folklorda, zamanın şiirinin "entelektüel niteliğini taşıyacak yetenek olmadığı"nı düşünüp ona karşı mesafeli duran (Süreya, 1992, s. 23) İkinci Yeni şairleri aksine, folklorik en küçük unsura bile ilgiyle yaklaşmak niyetindedirler. Onların sosyalizm yorumunda Anadolu halkı, en önemli yapıcı öğe konumundadır. Özel'in Ataol Behramoğlu'na mektubunda "beynim hep yaratılacak büyük Türk halkı ile meşgul" derken kastettiği şeyde, dönemin ruhunun yansıdığını söylemek yanlış olmaz. Nitekim dönemin şairleri bir dergi çıkarmak istediklerinde, "Halkın Dostları" adını seçeceklerdir. Bu tercihin, Lenin'in narodnik hareketini izah için yayımladığı “Halkın Dostları Kimlerdir?" broşürüne bir göndermeden fazlasını ifade ettiği açıktır. Bu bakımdan Özel'in "Yaşatan" şiirinin sonuna aldığı Gaziantep yöresine ait bir türkünün içerdiği anlam, şairinin yaşama tutkusunu ortaya koyduğu kadar halka bağlılığını da ifade etmektedir. Dönemin şairlerinin İkinci Yeni şairleriyle olduğu kadar Türk şiirindeki öteki halkçı yönelimlerle de süren poetik ve politik mücadelesinin önemli bir veçhesi kanaatimizce burada bulunabilir:

Yaşamak güzeldir

gözlerim daha güzel

gözlerim daha güzel halka bakınca

ve sürülmüş toprağı

yaratkan beyni

işleyen elleri huylandıran bakışlarım

yani insan türünün var kılanhız

yani hatta tarlalarda

döl yataklarında bile oyalanmayan

savaşın, sevdanın rengi

her güzellik bu rengin ardındadır

yaşamak bir başına bu rengi geçebilmez

'ölümden korkup da sonunu sayan

Ölür gider yar koynuna giremez.' (Özel, 1969, s. 23) 
İsmet Özel'in halka yönelik, kendi içinde sorunlar, sorgulamalar da barındıran bu bakışı, şairin 12 Mart 1970 muhtırası sonrası yaşadığı köklü değişim neticesi başka boyutlar kazanır. Özel, muhtıra sonrası ontolojik bir sorgulama içine girer. Kendi ifadesiyle "inziva"ya çekilir. Sosyal hayattan el etek çekmez ama "düşünmenin gücüne varma"ya çalışır. Bu, şair açısından, 1974 yılında yayımladığı "Amentü" şiirine kadar sürecek uzun bir sorgulama dönemidir. Bu dönemin sonunda Özel, "ihtida” eder:

"Varlığımı borçlu olduğum, doğru mu eğri mi davrandığımı karara bağlayan olabilirdi ancak. Böylece öteden beri sahip olduğum ve beni kendimi kandırmaktan alıkoyan deus otiosus inancı, içimde İslam itikadının Allah, Kadir-i Mutlak inancına inkılâp etti. Ateş'ten uzak kalmayı, Bahçe'ye girmeyi isteyen biri olma güvenine (ve belki safiyetine) sahip oldum. Elhamdülillah" (Özel, 1991, s. 78).

"Amentü" şiiri, bu bakımdan, şairin yaşadığı sürecin geldiği nokta olarak tebellür eder.

Özel'in yaşadığı bu değişiminin izleri, 1971 yılında Halkın Dostları'nda çıkan "Kötü Şiirler"den 1974'te Diriliş dergisinde yayımlanan "Amentü"ye kadarki şiirlerinde takip edilebilir. Bilhassa 1973 yılında Yeni Dergi'nin aynı sayısında yayımlanan "Kanla Kirlenmiş Evrak”, “Karlı Bir Gece Bir Dostu Uyandırmak”, "Propaganda” ve "Tahrik” şiirleri, şiiri "insanın duruşu", "objektifikasyonu" olarak gören Özel'in, iç dünyasındaki değişimleri, sorgulamaları göstermesiyle göze çarpar (Özel, 1991, s. 78). 12 Mart Muhtırasında herhangi bir baskıya maruz kalmamasına rağmen şair, askerî darbe ortamının getirdiği atmosferin etkisiyle yeniden ilk kitabı Geceleyin Bir Koşu'nun atmosferine dönmüş gibidir. Bu nedenle de şiirlerinde romantik bir sevgiyle, tutkuyla yaklaşılan "halk" görünmez olur. Yaşama olan bağlılık da benzer şekilde geri plana düşer. Özel'in ilk şiirlerindeki kendini yüceltme arzusu yeniden belirginlik kazanır:

Benim adım insanların hizasına yazılmıştır.

Her gün yepyeni rüyalarla ödenebilen bir ceza bu.

Keşke yağmuru çağıracak kadar güzel olmasaydım

ölüm ve acılar çatsaydı beni

düşüncem yapma çiçekler kadar gösterişli ve parlak

sözlerim ihanete varacak doğrulukta olsaydı (Özel, 1973, s. 38).

Özel, bu süreçte, Ataol Behramoğlu ile birlikte yayımlamaya başladıkları Halkın Dostları (Mart 1970) dergisinin yayın yönetmenliğini bırakır. Sadece halka bakışı değil hayata dair her düşüncesi bir değişim geçirmektedir."Bir şeyler yapmanın değil bir şeyler yapmama”nın önemli olduğu düşüncesiyle hareket etme gayreti içindedir. Sosyalist olarak ulaşamadığını anladığı hedeflere, Müslüman olarak ulaşmak gibi bir fikre kapılmak istemez. "Halk"a karışarak yalnızlığından sıyrılan şairin "yalnızlık"ına verdiği anlam değişmiştir: 
“Benim yalnızlıktan kurtuluşum birinci aşamada emperyalizmin beni mahkûm ettiği cehaleti reddetmekle başladı. (...) Eğer yalnızlık bir yalıtılma haliyse, batı kültürü, batılı olmayan insanı asla sınırlarını aşamayacağı çitlerle kuşatmıştır. (...) Benim şiire önem emek verme ve politik bağlanmayı değerli sayma çabalarım doğrudan doğruya sahicilik arayışlarıma destek olan iki çaba olarak anlam kazandı. Yalnızlığı bir uyuşmazlık olarak yaşadım ve uyum sağlama gayretlerim bendeki yalnızlık kabuğunun birinci katını kaldırdı" (Özel, 1991, s. 88).

Yalnızlığı, bir Müslüman için hissedilir bir hal olmaktan uzak olarak gören Özel için, İslam ümmetinin bir parçası olmak ne anlama gelmektedir? Sosyalistken "halk"a romantik duygularla bağlanan ama her durumda "halk" ile arasında bir "derece" farkı gören şairin, ihtida ettikten sonra, ümmetin bir parçası olarak din kardeşlerine bakışı nasıl olacaktır? Özel, bu iki hususta tabir caizse "tedbirsiz"dir: "Yeni bir çevre 'benim çevrem' olabilir miydi? Benim safiyane yaklaşımlarıma rağmen böyle bir vakıanın gerçekleşemeyeceğini bilmeliydim. Bir kere oluşumunu belli bir belirginliğe ulaştırmış, kendine özgü alışkanlıkları, algılayış biçimleri, tavır alış usulleri olan bir çevre ile yüz yüzeydim" (Özel, 1991, s. 89).

Yüz yüze geldiği bu yeni çevreye şairin bakışı, "Amentü" şiirinde ifadesini bulur. İhtida ettikten sonra şiirine büyük bir sevgi duyduğu Sezai Karakoç'a ulaşan Özel, şiirini onun dergisinde yayımlar. Dramatik şiir türüne has yanlarıyla dikkat çeken "Amentü", Özel'in sosyalist döneminde kaleme aldığı şiirlerinden biçim ve üslup bakımından farklılaştığı gibi halka bakış açısından da farklılık arz eder. Şair, baba figürü üzerinden, artık kendisine "halk" diyemeyeceğimiz, sosyalist bir bağ ile değil din, tarih ve dil bağıyla kaynaşabileceği daha büyük bir kesime yaklaşmak istemektedir. Onların mazur kaldığı insanî, siyasî badirelerde yanlarında olmak düşüncesinde olduğunu gösterir. Minbere haç dikilip ezanın susturulması kadar Türkçe okutulmasını da kabullenemez. Fakat İsmet Özel'in “ben”i sosyalistken olduğu gibi ihtida ettikten sonra da her şeyden çok kendi ile ilgili olmaya devam etmektedir.

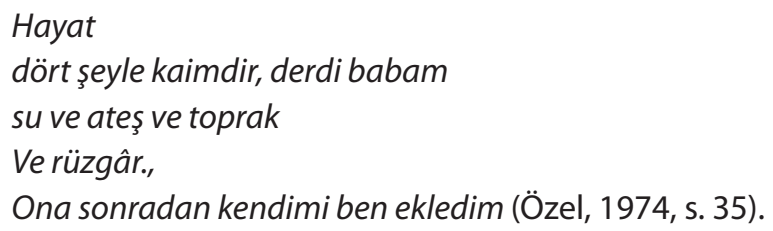

İsmet Özel, ihtida ettiğinin bir çeşit deklarasyonu diyebileceğimiz "Amentü" şiirine kadar geçen zamanda, pek az düzyazı kaleme alır. Bu döneminde o, kendini şiirle ifade etmeyi seçer. İhtidasından sonra ise, yoğun bir düzyazı faaliyeti içine girer. 1977 yayın hayatına başlayan Yeni Devir gazetesinde günlük köşe yazıları yazar. Denemeleri, makaleleri birbiri ardına yayımlanır. Bu bakımdan Özel'in ihtidası sonrasında Müslümanlar ile kurduğu bağın şiirin yanı sıra düzyazı ile de sürdüğünü, genişlediğini söylemek yanlış olmaz. 


\section{Bir Poetik Tercih Olarak Siyaset Algısı}

Şiir yazmaya başladığı yıllardan itibaren yalnızca Türkiye'deki değil dünyadaki sosyal ve siyasî olayları da yakından takip eden, üniversite yıllarında William Ebenstein'ın Siyasî Felsefenin Büyük Düşünürleri'ni tercüme eden İsmet Özel'in halka bakışı ile 1960-1980 dönemi siyasî olayları şiirlerinde yansıtışı paralellik arz etmektedir. Sosyalist döneminde de 1970'li yılların ortalarından sonra İslamcı bir dünya görüşünü benimsediğinde de şair, bireysel dünyasını toplumun içinde arama eğilimindedir. İdeolojik tercihlerinde değiş̧meyen yan, topluma dair ilgidir. Çalışmamamızın bundan sonraki aşamasında Türkiye'nin siyasî açıdan oldukça hareketli geçen 1965-1975 dönemine Özel'in, şiirleriyle yaptığı tanıklık üzerinde durulacaktır.

İsmet Özel, şiir ile ideolojiyi, bir heykelde bir araya geldiğinde varlıklarından bir şey kaybetmemesi gereken "bakır" ve "mermer" olarak niteler. Bir araya geldiklerinde bir estetik oluşturmaları oldukça güç olan bu iki unsuru şiir içinde gerektiği gibi kullanma meselesi, Özel'in zihnini meşgul eder. "Politik araştırmaları durdukları yerden çıkarmak, 'saf şiir' söylemini de günlük hayat içinde teşhis ettiğimiz gerçeklere bulaştırmakla" çözümü bulduğunu belirten şaire göre, bu ciddi bir sorundur (Özel, 1991, s.48). Şiir okuru da şair de bu sorunu ayrı ayrı hisseder. Şiir okuru, okuduğu şiiri, siyasetin söz dağarcığına, bilimsel hurafelerin mantığına tercüme eder. Bu nedenle "şiirle azdırılmış bir ideoloji" ve "ideolojiyle yere çalınmış bir şiir" özentisi etrafı kaplar. Benzer durum şairler için de geçerlidir. Şair, başkalarından öğrendiği doğruları şiirlerinde savunmaya başladığı zaman, o doğruların darlığından ya tıkanır ya da şiiriyle asıl vereceği şeyi kaybeder (Özel, 1991, s. 35). Sosyalist gerçekçi pek çok şairin şiir cevherlerini ideolog olma hevesiyle nasıl baskı altında tuttukları düşünülünce Özel'in bu tespitleri daha bir önem kazanmaktadır.

Bütün bu poetik güçlüklere karşın ideolojinin şiirde çeşitli yönleriyle görünen geniş bir tema olması, 1960-1980 dönemi şairleri için adeta bir zorunluluktur. İsmet Özel de sosyalist bir şair olarak, ideolojik duruşunun şiirlerine yansımasını önemser. "Halk"ı şiirleri için belirgin bir tema yaptığı kadar toplumun aktüel siyasî hayatını da şiirine taşır. Özel'in toplumun aktüel siyasî hayatını şiirlerine taşırken daha çok iki yola başvurduğunu söylemek mümkündür. Bunlardan ilki, medyaya yansıyan siyasî olayları şiirlerin içinde tematik bir unsur olarak doğrudan kullanmak şeklindedir. Bu kullanımın tipik bir örneğini 12 Mart 1965'te Zonguldak Kozlu'da gerçekleşen maden işçilerinin eylemlerinin şairin "Kan Kalesi" şiirine yansımasında görmekteyiz. Maden işçileri ile polis arasında yaşanan çatışma, o günlerin gazetelerinden Akşam gazetesinin 13 Mart 1965 tarihli nüshasına şöyle yansır: "Zonguldak'ta zabıta ile grevciler arasındaki çarpışma. İşçilere ateş açıldı. (...) Kozlu havzasında maden işçilerinin Perşembe gecesi vardiyaya girmemesinden doğan olaylar sonunda iki işçi ölmüş, 10 jandarma, 20'den fazla işçi ve deniz piyadesi yaralanmıştır." Gazete haber ve yorumunu hayatını kaybeden işçinin başında ağlayan ve dua eden arkadaşlarının fotoğraflarıyla somutlaştırmıştır. Aynı haberi dönemin hükümetinin bakış açısından veren 13 Mart 1965 tarihli Cumhuriyet gazetesinde ise haber şöyledir: "Kanunsuz 
grev büyüdü. Bir mühendis linç edilmek istendi. İki işçi de yaralandı. Kozlu'da ayaklanma. 6 bin işçi Kozlu'ya kimseyi sokmuyor. Asayişi temin için olay yerine bir tümen sevk edildi. (...) Gelik ocağında başlayıp Karadon, Kilimli ve Çaydamar ocaklarına sirayet eden huzursuzluk, Kozlu ocaklarında da baş göstermiş ve saat 24 vardiyası işçileri ocaklarına inmemişlerdir." İsmet Özel, Akşam ve Cumhuriyet gazetelerine yansıyan bu siyasî hadiseyi, hadiseden yaklaşık bir yıl sonra 1966 yılında yayımlan "Kan Kalesi" şiirinde şu dizelerle şiirleştirir:

şehri sarıyor, bir dehliz olan bana ulaşamıyor ama

herkesin içinde iğdiş bir bahar

bacakları eriyor memurların, evkızlarının

ve saat 24 vardiyasının işçileri

inmiyor ocaklarına (Özel, 1966, s.28-30).

Kozlu'daki maden iş̧̧ilerinin etrafında gelişen olayları veren Cumhuriyet gazetesinin kullandığı cümlelerden birinin devrik bir cümle haline getirilerek şiirin sonunda yer alması, şairin ülke sorunlarına yönelik ideolojik duyarlığını göstermektedir. Şair, bu tür hadiselerin karşısında halkın, işçilerin, devrimin yanında isyanı kuşanmış, sorumluluk duygusuna sahip bir kişilik olarak yer almaktadır.

İsmet Özel, 1969 yılında yayımlanan "Sevgilim Hayat" şiirinde bu defa ülke dışındaki sorunları, sosyalist devrimci bir duyarlıkla şiirine taşır. "Hayat"a sevgili olarak bakıp onu daha çok cinsel çağrışımlarla anan şair, yaşam ile savaşmak arasında bir bağ kurar:

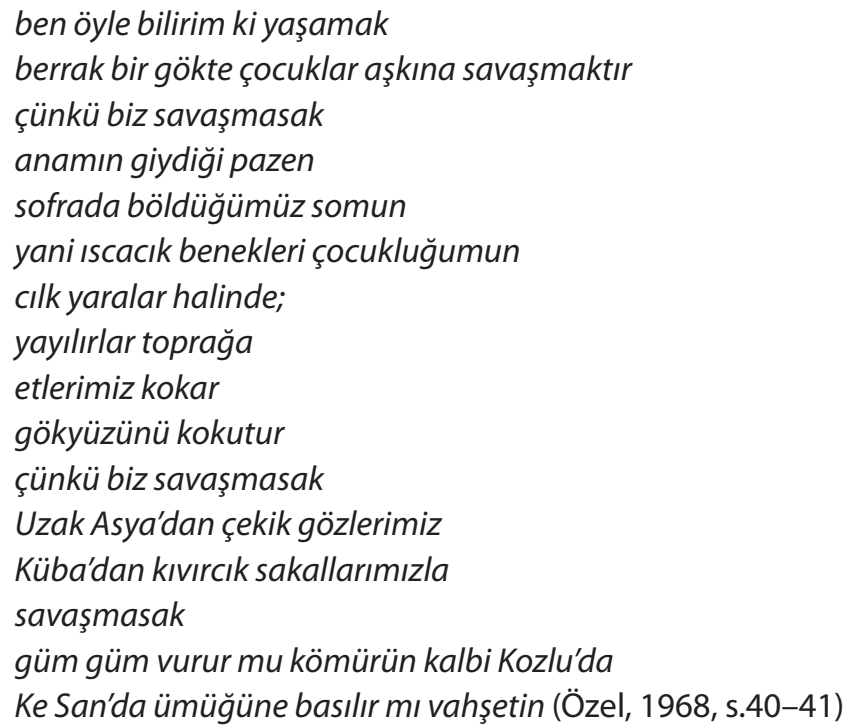

Şair, 1984 yılında Erbain adıyla şiirlerini toplu olarak yayımladığında "Sevgilim Hayat" şiirinin alıntıladığımız son dizesini Afganistan'ın bir şehri olan "Kandehar"ı da ekleyerek bu 
dizeyi: "Ke San'da Kandehar'da ümüğüne basılır mı vahşetin" şekline dönüştürür. Böylelikle şair, şiirin yayımlandığı tarihten yaklaşık on altı yıl sonra yaptığı müdahale ile bu husustaki hassasiyetini devam ettirdiğini göstermekte ve zulmün sadece ABD cephesine değil SSCB cephesine de işaret etmiş olmaktadır.

Özel'in siyasî hadiseleri şiirlerine taşırken kullandığı ikinci yol, kişi adlarıyla ya da sosyalist mücadele tarihinde yeri olan bir kavrama ya da hadiseye gönderme yapmak şeklindedir. Aktüel siyasî hadiselerin şiirde anılmak suretiyle canlılığın korunması isteği bu kullanımda da dikkat çeker. Şair, andığı kavram, kişi, ya da hadise ile hem kendisini hem de okurunu, adeta devrimci enerjiyle doldurmak ister. Bu tür kullanımlardan biri daha adıyla dikkat çeken "Partizan" şiiridir:

\author{
Gırtlağımda bir harf büyüyor \\ buna dayanacağım \\ dişlerim kamaşıyor yıldızlardan \\ buna da. \\ Kabaran bir çarpıntı oluyor şehir. \\ Artık yırtarak açtığımız zarflarda \\ ne kargış, ne infilak \\ yalnız \\ koynunda çaresiz, çıplak \\ isyan işaretleri taşıyan \\ bir ergen cesedi. \\ (...) \\ ÇIKSAM \\ gök \\ şarlayarak devrilse ardımdan \\ - ölürsek bir partizan gibi ölmeliydik - \\ yürüsem parçalanmış bir ceset tazeliğinde \\ yürüsem beynimde kıpkızıl bir serinlik \\ sonra denizler devirebilirim dudaklarımdan \\ sonra aşk, sonra dirlik: partizan (Özel, 1966, s. 6)
}

Adnan Onart'a göre bir partiye ya da gruba mantığa başvurmadan destek veren ve bir ülkeyi istila etmiş düşmana karşı yıpratma savaşı yürüten kişi olarak tanımlanabilecek partizan kelimesini ilk defa Nâzım Hikmet'in kullanmış olması kuvvetle muhtemeldir (Onart, 1968, s.17). Nâzım Hikmet, Memleketim'den Insan Manzaraları́nın dördüncü kitabında Almanlar'a karşı mücadele eden Zoe adında on sekiz yaşındaki bir genç kızın asılışını şiirleştirir. Düşmana ait bir ahırı yakarken yakalanan Zoe, ertesi sabah köyün meydanında kurulan bir darağacında asılır: 
Göğsüne bir de yazı astılar:
PARTiZAN
Köyün alanında kuruldu darağacı.
Atlılar çekmiş kılıcı
Halka olmuş piyade askeri
Zorla seyre getirdiler köylüleri
(...)
Partizan çıkarılıp kaldırıldı tahtına
Partizan
Kolları bağlı arkadan
Durdu urganın altında dimdik (Hikmet,1993, s.102)

Nâzım Hikmet'in bu tür bir anlatımla sempatik bir hale soktuğu "partizan" kelimesi, Özel'in şiirinde oldukça sert bir hüviyet kazanır. Şair, "bakır" ve mermer" gibi birbirini nakzeden iki unsuru, "şiiri" ve "ideoloji"yi bir bileşime dönüştürme çabasındadır. Buna işaret etmek için Edip Cansever, İsmet Özel'e: “Bu şiirde partizan kelimesi yerine haziran kelimesini koysan hiçbir şey değişmez" der (Özel, 1985, s. 33). Ancak şair, sosyalist bir şair olarak siyasî"bağlanma"sının gereğini yapan bir şair olmak istemektedir. Ataol Behramoğlu, o günlerde yaşadıkları psikolojiyi şu sözlerle dile getirmektedir:

"(...) Türkiye İşçi Partisi için dövüş, neredeyse yaşamımızın tümüydü. Tutkunluğumuzda, bilinçlilik kadar ve belki de daha çok devrimci bir romantizmin de etkisi olduğunu bugün kavrıyorum. Toplumcu kavgayla birden ve böylesine yoğunlukla karşılaşan bir genç kuşak için anlaşılır bir şeydir bu. Partizan o günlerin duyarlılığını yansıtır ve 1960 sonrası devrimci gençliğin yeni duyarlıklarını yansıtan ilk şiirdir. Bu anlamda gerek İsmet'in şiirinde gerek 1960 sonrası şiirimizde önemli bir yeri vardır" (Behramoğlu, 1975, s.18).

"Partizan" şiirini eleştirel bir incelemeye tabi tutan Adnan Onart, şiirde devrimciliğe çocuksu bir özenti ve burjuva rahatlığından kurtulma arzusu bulur. Ona göre, bu yüzden şiirde toplumcu bir öz bulmak doğru değildir. Zira bilinçli bir düşünüş yoktur (Onart, 1968, s.18). Bir çocuğun kovboyluğa ya da bir gencin çeteciliğe hayranlığı söz konusudur. Talat Kırcan da benzer bir yorum yaparak şiiri "devrimci romantik" bulur. Ataol Behramoğlu ise, şiirin bir dizesinde Fidel Castro'nun adının geçmesi ile Özel'in bu dönemde yazılan bir başka şiiri "Bir Devrimcinin Armonikası"nda "Hanoy'da bir uçaksavar" mısraını beraber düşünerek, bu durumun "özentisel" olsa da şairin devrimci "enternasyonale açılma"sı şeklinde değerlendirir (Behramoğlu, 1975, s. 21).

Şiir ile siyasî bağlanma arasında denge arayışı meselesi, Özel'in içinde olduğu 1960 Kuşağı için hayatî bir meseledir. İlk şiirlerini 1960'lı yılların başlarında İkinci Yeni şiirinin etkisi altında kalarak yazan İsmet Özel, Ataol Behramoğlu, Süreyya Berfe, Özkan Mert gibi 
isimlerin siyasîhadiselere karşı gösterdikleri ilgi, 1960'lıyılların ortalarına doğru değişmeye başlar. Sözgelimi İsmet Özel, Türkiye'deki sosyalist siyasî hareketi temsil eden Türkiye İşçi Partisi'ne,1963 yılında kayıt olur. 1965'de yapılan genel seçimlerde parti adına görevler üstlenir. Benzer durum, andığımız diğer isimler için de söz konusudur. Illk şiirlerinde İkinci Yeni şiirinden etkilenen bu isimler, 1960'lı yılların sonlarına gelindiğinde, İkinci Yeni şairlerine karşı bir tutum takınıllar. Onlara göre İkinci Yeni şairleri, Türkiye'deki siyasî hadiseleri, şiirlerine gereğince yansıtamamakta ve daha önemlisi bu hadiselerin sosyalist bir çizgide yürümesi uğruna aktif bir siyasî eylem içinde olmamaktadırlar. 1969 yılında haftalık yayın yapan Ant dergisinde Osman Saffet Arolat'ın düzenlediği “Devrimci Genç Şairler Savaş Açıyor" başlıklı soruşturma, İkinci Yeni şairleri ile İsmet Özel'in de aralarında bulunduğu bu kuşağın, şiir ile siyaset arasında kurdukları ilişkiye açıklık getirmesi bakımından mühimdir. 2, 9, 16 Aralık 1969 tarihlerinde artarda üç hafta gerçekleştirilen soruşturmanın sunuşu şöyledir: "Türkiye'de son yıllarda kavganın içinden gelen, yaşadığı olaylarla soluklanan genç sanatçılar güçlü sesleriyle seslerini duyurmaktadırlar" (Arolat, 1969, s.14). Bütünüyle kurgulanmış olduğu açık olan bu soruşturmada hedef, "gerici sanat" anlayışı olarak nitelenen sağcl, idealist sanat anlayışından daha çok 1954-1959 arasına yerleşen "Ikinci Yeni gericiliği"dir. Özel, Behramoğlu, Berfe ve Mert, toplumcu sanat anlayışını benimseyen şairler olarak açık ve kıyasıya bir kavgaya giriştiklerini, gelmekte olan nesli zararlı sanat etkilerinden korumayı amaçladıklarını ifade ederler. Siyasî tercihlerini aktif bir siyasî eyleme dönüştürmeyen, bunun yansımalarını da şiirlerinde ortaya koyamayan İkinci Yeni şairleri, onlar için tasfiye edilmesi gereken isimlerdir.

Mart 1969'da Halkın Dostları dergisinin "Gerici Sanata Hücum" sloganıyla yayın hayatına başlaması da bu doğrultuda bir girişim olarak değerlendirilebilir. İlk on iki sayısı İsmet Özel yönetiminde çıkan Halkın Dostları, Özel'in "Partizan" şiirinde ortaya koyduğu poetik tutumun bir devamıdır. Bu bakımdan İsmet Özel'e, şiirde "partizan" kelimesi yerine "haziran" kelimesinin yer almasının hiçbir şeyi değiştirmeyeceği eleştirisinde bulunan Edip Cansever, Özel ve kuşağının 1965-1970 döneminde kabullenmelerinin zaman alacağı, bazısının ise hiçbir zaman kabullenemeyeceği bir argümanı dile getirmektedir. Bu durumu Özel'in şu sözlerinde bulmak mümkündür: "Partizan sözünü anlamak için sözlüğe değil şiire bakmak kaçınılmazdı. Çünkü taraf olmanın üstünlüğü, kendine akarak boğulanların karşısına konulmaktaydı ve (işin garip tarafı)nihaî tavır olarak sunulmamaktaydı. Nitekim bir süre sonra bir partizanın armonikasında kurtulmaktan değil 'boğulmak'tan söz edecektim" (Özel, 1991, s. 48). Süreyya Berfe, Ant dergisindeki çıkıştan kısa bir süre sonra, tutumunu değiştirir. Halkın Dostları'nda yer almaz. İkinci Yeni şairlerine karşı böylesine bir cephe açmanın yanlış olacağı kanaatine varır (Berfe, 2005, s. 139). İsmet Özel, 1970 muhtırası sonrası girdiği sorgulamaya süreciyle birlikte zaman içinde fikirlerindeki katılıktan uzaklaşır. Ataol Behramoğlu, Nihat Behram ve Özkan Mert ise aynı düşüncelerle hareket etmeye devam edeceklerdir.

Esasen Íkinci Yeni şairleri de 1960'lı yıllar boyunca toplumsal meselelere yabancı bir tutum sergilememişlerdir. Ancak onların poetik tercihleri, siyasî bir angajmanın getirdiği 
türlü görüntüleri şiire taşımak şeklinde bir kolaycılık içinde değildir. "Eylem halinde olmak” hususunda da farklı düşünürler. Böylesi bir tutumun şairin şiirlerini yaşanan zamanla sınırlaması, poetik bir sorun olarak karşımıza çıkabilir. Nitekim 1960'lı yılların siyasî hadiselerini, işçi ve öğrenci olaylarını şiirin kalitelerini hesaba katmaksızın şiirleştiren pek çok şairin bu girişimleri, yaşanan zamanın içinde bir anlam taşısa bile kalıcılık arz etmemiş̧ir. Sözgelimi 1963 yılında Kavel kablo fabrikasındaki işçi direnişini şiirleştiren Hasan Hüseyin'in aynı adı taşıyan kitabı da yukarıda mevzubahis ettiğimiz Kemal Özer'in eserleri gibi yaşanan zamanla sınırlı kalmıştır. Özel ve Cansever arasında, "partizan haziran" kelimeleriyle akıllarda yer eden diyalog, İkinci Yeni şairleri ile Özel ve kuşağının poetik tercihlerindeki farklılığa işaret eder. Bu noktada beliren farklılık, kanaatimizce, 1920'li yıllarda Nâzım Hikmet'le başlayıp 1940'ı yılların başında yayınlanan Yeni Edebiyat dergisi ile ilerleyen ve 1965-1980 boyunca devam eden sosyalist gerçekçi sanat anlayışı ile İkinci Yeni sanat anlayışı arasındaki farklılığın ötesindedir. Birçok nedeni, boyutu, olguyu, tartışmayı bünyesinde barındırır. Nitekim İsmet Özel'in de içinde bulunduğu 1960 kuşağının sosyalist gerçekçi şairleri, kendilerinden önce bu anlayışla şiirler yazan isimlerden Nâzım Hikmet ve Ahmet Arif'i yaşadıkları dönemin şairleri olmakla eleştirirler. Eleştirdikleri isimlerden Ahmet Arif de, adları Halkın Dostları ile anılan isimleri, Ant dergisi ve sonrasındaki çıkışlarındaki tutarsızlıkları nedeniyle eleştirir (Özel, 1971, s. 2). Benzer durum, 1970'li yılların sosyalist gerçekçi şairleri arasında da söz konusudur. Onlar da hem kendilerinden önceki kuşağa hem de birbirlerine karşı eleştirel tutum takınırlar (Bilen, 1985, s. 8-150). Genç şairlerin şiirlerinin tebarüz edebilmesi için giriştikleri tartışmaların da ateşlediği bu gibi poetik fikir ayrılıkları, bilindiği gibi, kuramsal tutumlara, siyasî tercihlere, şairlerin mizaç farklılıklarına kadar genişleyen birçok nedenden kaynaklanabilmektedir. Türk edebiyatında sol edebiyat hareketleri bu yanıyla oldukça zengin bir görünüm arz eder (Kılıç, 2012, s. 7-246).

İsmet Özel, 1970- 1974 yılları boyunca yaşadığı ihtida süreci ve sonrasında da şiirlerinde siyasî hadiseleri farklı şekillerde çağrıştırmaya devam eder. Ancak önceki döneminde olduğu gibi siyasî hadiselere doğrudan gönderme yapmaz. Metaforlar yoluyla hissettirir. Sözgelimi 1970-1974 döneminde "inziva"yı tercih eden şair, bir ihtida dönemi yaşamasına, sosyalist dünya görüşünden İslamcı bir dünya görüşüne meyletmesine karşın, bu dönemin siyasî atmosferini sosyalist bir gözle yansıtmaya devam eder. "Amentü" şiirine kadar devam eden bu sürecin en dikkat çeken şiirlerinden biri “Esenlik Bildirisi” şiiridir. Özel'in ikinci şiir kitabı Evet, İsyan'ı oluşturan sert, mücadeleci, yıkıcı söyleyişin en üst perdeye ulaştığı şiir, yaşanan zamanın şair açısından arz ettiği boğucu atmosferi resmeder. Şairin bu atmosfere karşı tutumu yıkma, yok etme isteği şeklindedir:

Duygular paketlenmiş, tecime elverişli gövdede gökyüzünü kışkırtan şiir sahtedir gazeteler tutuklamış dünya kelimesini o şiirden o dünyadan öcalmalı demektir. 


\title{
Vandal yürek görün ki alkışlanasın \\ ez bütün çiçekleri kendine canavar dedir \\ haksızlık et haksız olduğun anlaşılsın \\ öcalınmazsa çocuklar bile birden büyüyebilir (Özel, 1973, s. 41)
}

\begin{abstract}
"Amentü" şiirinin Diriliş dergisinde yayınlanmasıyla birlikte Özel'in ihtidası, tabir caizse tescillenmiş olur. Sol çevrelerde bu hadise büyük bir şaşkınlık yaratır. Ataol Behramoğlu, "Amentü" şiirinin yayımlanmasından kısa bir süre sonra siyasî ve edebî yanları itibariyle Halkın Dostları'nın devamı sayılabilecek Militan dergisinde "Ismet Özel Üstüne" başlıklı uzun bir yazı kaleme alır. Özel'in şiirlerindeki metafizik eğilimi ilk şiirlerinden başlayarak tespit etmeye çalışır:
\end{abstract}

“Evet, İsyan'ın ilk şiirlerinde alttan alta sürdüğü görülen ergenlik bunalımları, onun bu duyguları tümüyle aşamadığın kanıtıdır. Aceleciliğinde Geceleyin Bir Koşu'dan Partizan'a geçiverişinde) 'bir başkası' olmayı denemenin payı vardır. Aynı şey bu kez Akdeniz'in Ufka Doğru Mora Çalan Mavisi'nden Amentü'ye geçişi için söz konusudur. Yine 'bir başkası' olmayı denemek gereksinmesi... İsmet Özel, Evet, İsyan'ın ilk şiirlerinde bütün isyancı tonuna karşın, henüz yeterince toplumcu olamayacak kadar ergenlik boğuntularıyla doluydu. Bugün de onun yeterince dindar olamayacak kadar aynı boğuntuların etkisi altında olduğu ve üstelik (gerek Evet, İsyan'ın gerek son kitabın birçok şiirinin açıkça kanıtladığı üzere) kişiliğinde toplumcu bir dünya görüşünün derinliğine izler bıraktığı kanısındayım" (Behramoğlu, 1975, s. 141-143).

Behramoğlu'na göre, Özel'in bağlandığı idealist dünya görüşü büyük bir şiire kaynaklık edemeyecektir. Özel'in sahip olduğu şiirsel yetenekler, belki bir süre ona "ilginç görünümlü" şiirler yazdıracaktır ancak mesele öze gelip saplandığında bir açmaz söz konusu olacaktır.

Behramoğlu'nun bu görüşlere yer verdiği Militan dergisi, 1970'li yılların ortalarından başlayarak Türkiye'de sosyalist eylemciliği destekleyen bir yayın faaliyeti yürütür. Ataol Behramoğlu ve kardeşi Nihat Behram'ın yönetiminde çıkan derginin poetik ve politik duruşunu, Nihat Behram'ın 1976 yılında yayımlanan Dövüşe Dövüşe Yürünecek kitabının adı ortaya koymaktadır (Behram, 1976, s. 5-78). Kapağında, eylemcileri ellerinde coplarla karşılayan polislerin yer aldığı kitaptaki şiirler, Türkiye'de sosyalist gerçekçi şiirin 1970'li yıllara geldiğindeki durumunu irdeleyebilmek bakımından üzerinde ayrıca durulmaya değerdir. Öte yandan İsmet Özel, "Amentü" şiiri ile başlayan yeni sürecinde, şiirlerine, reel politiğin görüntülerini yansıtmaktan ziyade geniş ve derinlemesine tarihsel, sosyolojik, psikolojik yorumlarda bulunmayı seçecek ve bu şiirlerini Cinayetler Kitabı (1975) adıyla kitaplaştıracaktır. 


\section{SONUÇ}

Edebî eserin sanatçının iç dünyasından izler taşıması kadar sanatçı kişiliği etkileyen siyasî hadiselerden izler taşıması da doğaldır. Toplumda siyasî çatışmaların yoğunlaştığı dönemlerde şairler, toplumsal sorumluluk duygusuyla hareket edip toplumu yönlendirme rolü üstlenebilirler. 1960-1980 dönemi Türk edebiyatında şairlerin, yazarların böylesi bir sorumluluk duygusuyla hareket ettikleri bir dönemdir.

İsmet Özel, ilk şiirlerini yayımladığı 1960'lı yıllardan bugüne şiirleri ve fikirleri ile Türk edebiyatını olduğu kadar fikir hayatını da etkilemiş bir isimdir. Illk şiir kitabı Geceleyin Bir Koşu'da bireysel dünyasındaki arayışlarını gözlemlediğimiz şair, 1965 yılından sonra sosyalist dünya görüşüne bağlanır ve bu ideolojik bağlanmanın yansıması olan şiirlerini birbiri ardına yayımlar. Bu eserler yayımlandığı dönemlerde oldukça ses getirir. 1969'da yayımlanan Evet, İsyan ve 1975 'te yayımlanan Cinayetler Kitabı, onun sosyalist bir şair olarak siyasî, toplumsal hadiselerle yakından ilgilendiği bu döneminin eserleridir.

Özel'in 1965-1975 dönemi şiirleri, şairin bir ergen genç olarak iç dünyasından çıkıp topluma, halka karışmasının sancılarını, arayışlarını yansııır. Halk, dönemin sosyalist gerçekçi şairlerinin tümü gibi onun için de devrim umudunun taşıyıcısıdır. Ancak Özel, halka devrimci romantik duygularla yaklaştığında bile eleştirel olmaya çalışır. Halka dair sevgisi coşkundur ama o sevginin belirleyicisi şairin benliğidir. "Halksa kal'am onu kal'a kılan benim", diye düşünen Özel, Halkın Dostları dergisini birlikte çıkardığı şair arkadaşı Ataol Behramoğlu'na yazdığı mektuplarında da bu durumu vurgular. Bir yandan sosyalist bir "Büyük Türk Milleti"nin nasıl yaratılacağını düşünür öte yandan da o milletin halkının gerekli nitelikleri taşımadığını gözlemler. Bu bakımdan Özel'in halka bakışının "ikircikli" olduğunu söylemek mümkündür.

1965-1975 dönemi Türk siyasî hayatının en sancılı dönemlerinden biridir. 1960 askerî darbesinin üzerinden geçen zamanda iş̧̧i ve öğrenci olaylarında belirgin artışlar söz konusudur. 12 Eylül 1980 askerî darbesini hazırlayan şartlar oluşmaktadır. Böylesi bir dönemde İsmet Özel, Türkiye içinde ve dışında cereyan eden siyasî olayların aktüel olanları olduğu kadar üzerinden bir zaman geçmiş olsa da etkileri devam edenlerini de şiirlerine yansıtır. Zonguldak Kozlu'da gerçekleşen grevin gazetelere yansıyan çeşitli veçheleri, Özel'in şiirleri içinde de yerini alır. Bunun yanında Özel, şiirlerinde sosyalist mücadelenin tarihi açısından mühim olan bazı kavramlara ve kişilere de göndermeler yapar. Bu sayede onların içindeki sosyalist mücadele cevheri yaşanan zamana taşınmış olur. Adnan Onart, Talat Kırcan gibi dönemin kimi eleştirmenleri Özel'in bu tutumunu "devrimci romantizm" ve "özenti" bularak eleştirmiş olsalar da şairin bu şiirlerinin şairler üzerinde etkili olduğunu söylemek yanlış olmaz. Özel, kuşağının poetik ve politik tutumunun yansıması diyebileceğimiz bir sürecin içinden geçmektedir. Ataol Behramoğlu, Süreyya Berfe ve Özkan Mert'in de içinde olduğu bu kuşak, siyasî bir eylem içinde olmayı istemekte ve şair için böylesi bir bağlanmayı gerekli saymaktadır. Bu 
bakımdan Halkın Dostları dergisi, bu düşüncelerin yansıdığı bir edebiyat hareketi olarak da karşımıza çıkar.

İsmet Özel, şiirlerini sosyalist gerçekçi bir anlayışla yazdığı 1965-1975 döneminde, halka bakışı ve dönemin siyasî olaylarını şiirlerinde yansıtışı bakımından dikkate değer bir şairdir. Onun bu şiirleri, Türk şiirinde Nâzım Hikmet'ten Kemal Özer'e dek uzanan 19201960 dönemi sosyalist gerçekçi çizginin içinde hem kendine has yanlar taşır hem de bu şiir anlayışının gelişim çizgisini temsil etme vasfına sahiptir. Özel'in ilk şiir kitabında iç dünyasında sürdürdüğünü gördüğümüz "arayış", sosyalist bir devrimci olduğu dönemde, bu defa toplumsal, siyasî hadiseler içinde sürer. 1974'te yayımladığı "Amentü" şiiri ile İslamî bir dünya görüşünü benimsediğini deklare eden Özel'in arayışı, yeni boyutlar, poetik edalar, tutumlar kazanacak ve evvelce düzyazıya mesafeli görünen şairin, yazar olarak da edebiyatımızı, düşünce hayatımızı etkileyen dönemi başlayacaktır.

\section{KAYNAKÇA}

Arolat, O. S. (1969). Sanat soruşturması I: Devrimci genç şairler savaş açıyor. Ant, 153, 14-15.

Arolat, O. S. (1969). Sanat soruşturması II: Bir toplumun varlığı sanatıyla belirginleşir. Ant, 154, 14-15.

Arolat, O. S. (1969). Sanat soruşturması III: Halkımızın değerlerini yaşatmak, yaymak, yüceltmek dileğindeyiz. Ant, 156, 14-15.

Artun, A. (2016). Sanatın iktidarı, ekim devrimi, avangard sanat ve müzecilik. İstanbul: İletişim Yayınları.

Behram, N. (1976). Dövüşe dövüşe yürünecek. İstanbul: Militan Yayınları.

Berfe, S. (1969). Gün ola. İstanbul: FKF Yayınları.

Bilen, M. Y. (1985). 70 kuşağı şiirimizi tartışıyor. İstanbul: Yaba Yayınları.

Behramoğlu, A. (1975). İsmet Özel üzerine. Militan, 11, 24-43.

Behramoğlu, A. ve Özel, İ. (1995). Genç bir şairden genç bir şaire mektuplar. İstanbul: Oğlak Yayınları.

Gülendam, R. (2010). Siyaseti şiirde yaşamak: Cumhuriyet dönemi Türk edebiyatında sosyalist şiir. Turkish Studies, 5(2), 212-280.

Hikmet, N. (1993). Memleketimden insan manzaraları. İstanbul: Adam Yayınları.

Hikmet, N. (2012). Son şiirler. İstanbul: Yapı Kredi Yayınları.

Kılıç, M. B. (2012). Saklı rönesans Türkiye'de sol edebiyat hareketleri için bir hat. İstanbul: Notabene Yayınları.

Kırcan, T. (1970). Evet, İsyan. Soyut, 23, 20.

Moran, B. (1991). Edebiyat kuramları ve eleştiri. İstanbul: Cem Yayınevi.

Onart, A. (1968). Bir şiiri okumak. Soyut, 2, 17-19.

Özel, İ. (1966). Kan kalesi. Papirüs, 1966, 28-30.

Özel, İ. (1966). Partizan. Şiir Sanatı, 6-7, 6.

Özel, İ. (1967). Evet, isyan. Şiir Sanatı, 16, 28-29. 
Özel, i. (1969). Yaşatan. Yeni Dergi, 60, 32-33.

Özel, ì. (1971). Ahmet Arif'e dostça bir açıklama. Halkın Dostları, 11, 1-2.

Özel, İ. (1973). Karlı bir gece bir dostu uyandırmak. Yeni Dergi, 102, 38-39.

Özel, ì. (1973). Esenlik bildirisi. Yeni Dergi, 111, 41.

Özel, ì. (1974). Amentü. Diriliş, 1-2, 32-35.

Özel, İ. (1985). Haziran gibi ölmek. Yeni Gündem, 21, 33.

Özel, İ. (1991). Waldo sen neden burada değilsin? İstanbul: Çıdam Yayınları.

Oktay, A. (1986). Türkiye'de toplumcu gerçekçiliğin kaynakları. İstanbul: BFS Yayınları.

Özer, K.(1959). Gül yordamı. İstanbul: Yedi Tepe Gazetesi ve Yayınları.

Rieman, W. (1998). Yeni edebiyat dergisi (F. Gökçek, Çev.). Türk Dili ve Edebiyatı Araştırmaları Dergisi, 8, $161-170$.

Troyat, H. (1991). Gorki. (Ö. Arıkan, Çev.) İstanbul: Telos Yayınları.

Süreya, C. (1995). “555K” Sevda sözleri. İstanbul: Yapı Kredi Yayınları.

Saunders, S. F. (2016). Parayı verdi düdüğü çaldı, sanat ve edebiyat dünyasında CIA parmağı (Ü. İnce, Çev.). İstanbul: İmge Kitabevi.

Sezer, S. (2008). 68'in edebiyatı edebiyatın 68'i. İstanbul: Evrensel Basım Yayın.

Süreya, C. (1992). Folklor şiire düşman. İstanbul: Can Yayınları. 
